ро н лізов но зміни н земного покриву, як центр льного компонент біогенних геоекосистем, щодо структури природних л ндш фтів, тр нспортної інфр структури т структури землекористув ння. ля дослідження обр но п'ять модельних сільських р д у низькогір'і кр їнських

рп т. к основні д ні використ но р дянські топогр фічні к рти т високороздільні космічні знімки. ісля поєдн ння структури суч сного н земного покриву з к ртогр фічним ш ром природних морфогенних геоекосистем визн чено біогенні геоекосистеми. ри виділені кл си н земного покриву д ли змогу розрізнити шість н прямів у дин міці геоекосистем. Г льною тенденцією є зрост ння лісистості з вдяки дегр д ції колишніх сільськогоспод рських угідь.

лючові слов : кр їнські рп ти, геоекосистеми, н земний покрив, суч сн дин мік ,

береження і ст ле використ ння біотичного т л ндш фтного різном ніття в різних сфер х суспільств передб чене міжн родними норм тивними кт ми, які були р тифіков ні кр їною [7, 8]. езв ж ючи н це, впродовж ост нніх двох десятиліть відбулися зн чні соці льно-економічні перетворення в укр їнському суспільстві, що т кож відобр зилось н використ нні ресурсів л ндш фтів для суспільних потреб. еобхідною передумовою викон ння взятих кр їною н себе зобов'яз нь $\in$ н явність різном нітних геод них, у тому числі про структуру т суч сну дин міку л ндш фтів. осягнення зб л нсов ного розвитку, особливо гірських регіонів, з лежить від ур хув ння т ких д них у ході пл нув ння т проведення господ рської діяльності. роте суч сний ст н і суч сн дин мік н земного покриву ( ) л ндш фтів (після 1980-х років) досліджені явно недост тньо. ому для території кр їнських рп т поки що існує н дто м ло інформ ції щодо суч сних змін у л ндш фт х i, особливо, отрим ної н підст ві - н лізу великом сшт бних геопросторових д них.

ослідження території кр їнських рп т проводять уже трив лийч с. їхніми результ т ми з'ясов но не лише вл стивості окремих компонентів природи, й особливості їхнього поєдн ння в л ндш фтних одиницях різного р нгу. оловні результ ти т ких досліджень підсумов ні у регіон льних моногр фіях, які охоплюв ли всю територію кр їнських рп т $[19,23]$ бо стосув лись окремих їхніх ч стин [18]. о3роблено т кож регіон ліз ції т к рти типів л ндш фтних місцевостей цієї території $[12-14,16]$. ещо кр ще у літер турі висвітлено л ндш фтні особливості трийськоянської ерховини, де розт шов н одн з модельних сільр д $[10,22]$. кож опубліков но н комп кт-диску -д ні про природні регіон льні т лок льні геоекосистеми у б сейні ерхнього ністр з точністю м сшт бу 1:250 000 [27]. крім того, ми опублікув ли м тері ли про морфологію природних л ндш фтів н територію усіх п’яти модельних ділянок [21].

(C) м лійчук ., 2012 
ивчення нтропогенних змін кр їнських рп т розпоч то ще в $р$ дянський період. с мперед, н звемо колективну пр цю під керівництвом . олубця [3], у якій опис но з г льні н прями змін біогеоценотичного (рослинного) покриву ескидів упродовж ост нніх двох століть. і дослідження отрим ли продовження, з вдяки чому, зокрем , з пропонов но реконструкцію первинного біогеоценотичного покриву північногосхідного м кросхилу кр їнських рп т [9]. кож були спроби вивч ти цю проблем тику н рівні окремих дміністр тивних р йонів [2] бо сільських р д [1]. цих дослідженнях основну ув гу приділено кількісним пок зник м, н томість просторовому н лізу у цих пр цях відведено зн чно менше ув ги.

кий н ліз дет льно викон ний у серії міжн родних публік цій, які з'явилися ост нніми рок ми і стосув лися суч сного ст ну т тенденцій змін 3 хідної ч стини [30] бо кр їнських рп т з г лом [31]. пільною їхньою рисою є використ ння як вихідних д них різноч сових середньом сшт бних космічних знімків супутник Landsat TM/ETM+. окрем, створено середньом сшт бний к ртогр фічний ш р ( ) ст ном н 2000 р., що охоплюе $з$ хідну ч стину кр їнських рп т [29]. опередньо опубліков ні м тері ли про дин міку л ндш фтів н територію двох 3 п’яти досліджув них територій [20] уточнені в ході цього дослідження.

етою дослідження було н основі порівняння суч сних високороздільних космозобр жень т к рт р дянського періоду виявити й оцінити особливості тр нсформ цій

у лок льних л ндш фтних одиницях кр їнських рп т. б'єктом цього дослідження $є$ як центр льний компонент біогенних геоекосистем, предметом - його суч сн дин мік.

ля узгодження різних л ндш фтон вчих підходів потрібн гнучк і водноч с всеохопн основ , яку можн використ ти й для проведення прикл дних л ндш фтних досліджень. кою основою, н н ш погляд, може слугув ти вчення про геоекосистему ( ) [11], яке як і уявлення про л ндш фтно-територі льні структури (конфігур ції) . родзинського $[4,5]$, передб ч є використ ння принципу комплемент рності в ході вивчення зв'язків у л ндш фті. еоекосистему розгляд ємо як геопросторову модель вз ємозв'язків однієї з вл стивостей л ндш фту як системоформув льного компонент 3 іншими л ндш фтними вл стивостями (компонент ми). ип визн ч є системоформув льний компонент т х р ктер його геопросторових зв'язків з іншими компонент ми. и кцентуємо н біогенному типі , який є моделлю вз ємозв'язку кту льних біоценозів (природних і культурних) з іншими вл стивостями л ндш фту.

міни у л ндш фті н йпомітніше виявляються через рослинний, в ширшому розумінні - н земний покрив. ерез це кту льний н земний покрив обр но як ключовий компонент для виділення біогенних [11]. хоч інтегров ної теоретичної основи для вивчення змін $\mathrm{T}$ землекористув ння поки що не створено, очевидним $\epsilon$ необхідність вр хув ння як природних, т к і суспільних елементів під ч с дослідження т ких процесів [28].

ермін “н земний покрив” (land cover) ост нніми десятиліттями н був зн чного поширення в іноземних публік ціях для висвітлення результ тів природничих досліджень 3 використ нням д них дист нційних знім нь ( ) (н прикл д, [29, 30, 31]). йбільш 3 г льним є озн чення як фізичного м тері лу н земній поверхні [24]. кл довими ч стин ми поняття “н земний покрив" є рослинний покрив р зом із позб вленими рослинності природними (водні об'єкти, скелі) т створеними людиною об'єКТ ми н земній поверхні. цьому дослідженні в р зі диференці ції типів 3 основу бр ли життєву форму рослин - дерев , кущі т ч г рники, тр ви. 
о моделі л ндш фту як біогенної , окрім природних, логічно з числяємо т кож нтропогенно зумовлені л ндш фтні х р ктеристики, які, н н Ш погляд, вплив ють н суч сні тенденції змін

ериторія дослідження. кр їнські рп ти є ч стиною гірської системи, що простягнул ся територією восьми європейських держ в. и розгляд ємо ч стину північносхідного м кросхилу кр їнських рп т, як обмежен дміністр тивними меж ми ьвівської обл сті. я територія геологічно н лежить до лішових рп т т м йже повністю розт шов н у б сейні верхнього ністр . к модельні ділянки дослідження обр но території чотирьох сільських т однієї селищної р ди у низькогір'ї рп т у меж х ьвівської обл сті, с ме гуєвицьку (2 513,2 г ) рогобицького р-ну, мельницьку (2 061,4 г ) колівського р-ну, оберську (6 797,2 г ) т сесицьку (4 313,5 г ) сільр ди урківського р-ну т т росолянську селищну р ду (3 185,1 г ) т рос мбірського р-ну (рис. 1).

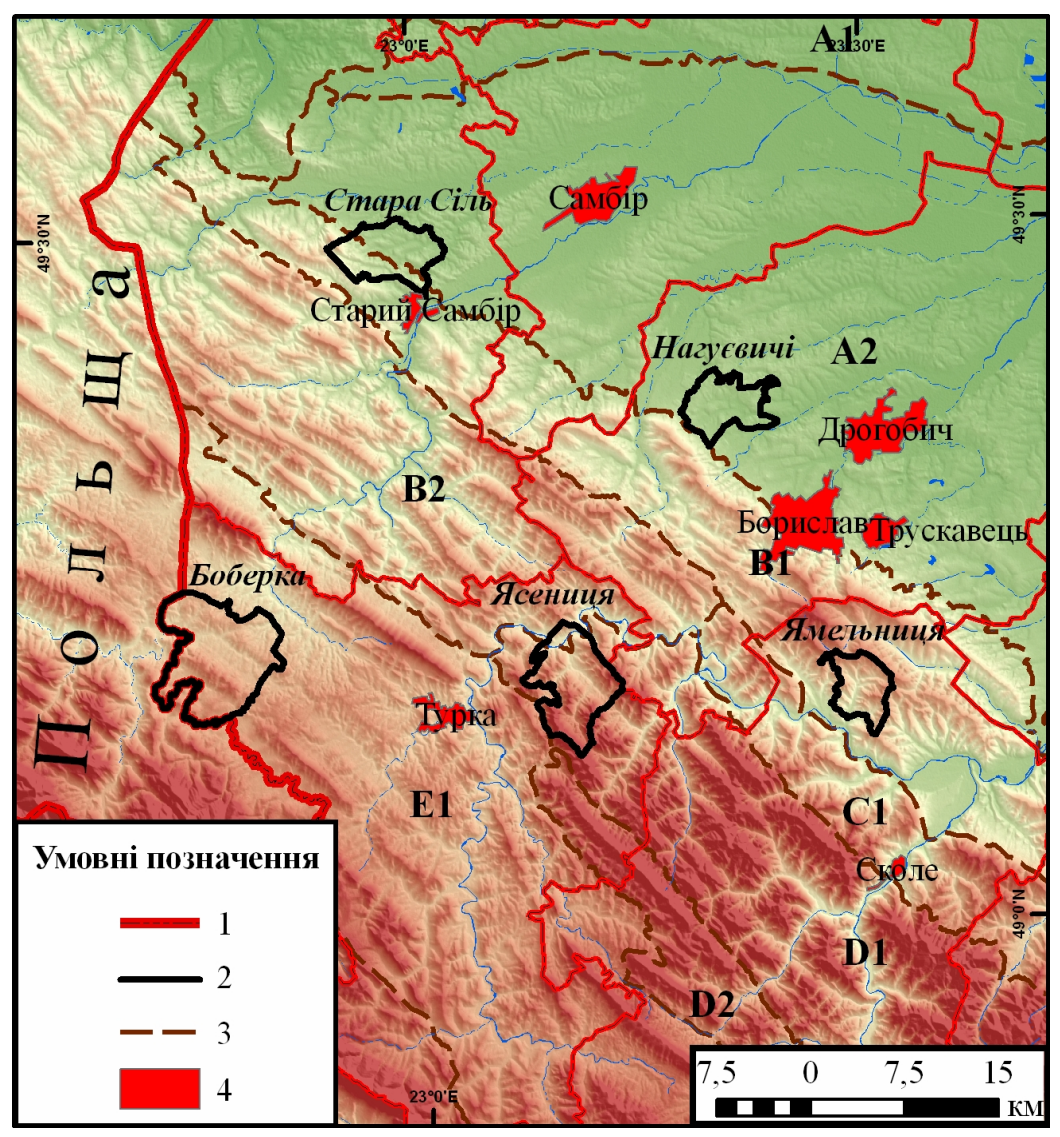

ис. 1. озміщення територій дослідження у системі природно-геогр фічного $\mathrm{p}$ йонув ння, $з$ $[12,27]$ : езоекорегіони: А1 - ишне- т вч нське межиріччя, А2 - ерхньодністерське ередк рп ття, В1 - p йові ескиди, В2 - ністерські ескиди, С1 - овнішні ескиди, D1 - ентр льні ескиди, D2 - нутрішні ескиди, Е1 - янсько- трийськ ерховин ; 1 - держ вний кордон; 2 - території дослідження; 3 - межі мезоекорегіонів; 4 - основні міст 
бр ні для дослідження місцеві р ди відрізняються не лише природними умов ми, т кож й історією т суч сним рівнем соці льно-економічного розвитку, тому, імовірно, м тимуть різні пок зники дин міки біогенних

ериторії модельних р д, згідно зі схемою екологічного (природно-геогр фічного) р йонув ння, розт шов ні в меж х декількох мезоекорегіонів, с ме: ерхньодністерського ередк рп ття, р йових, ентр льних і ністерських ескидів т янськотрийської ерховини $[12,27]$. бсолютні висоти н їхній території колив ються в меж х від 301 ( гуєвичі) до 1102 ( сениця) м н. р. м. лім тичні умови змінюються від теплих т помірно теплих у передгір'ї до прохолодних і дуже прохолодних у гірських $\mathrm{p}$ йон х. редк рп тті поширені бурув то-підзолисті поверхнево-оглеєні і неоглеєні т дернові грунти. томість у гірській ч стині регіону н йч стіше тр пляються буроземний гірсько-лісовий, у долин х водотоків - люві льні буроземні грунти [27] уч сний рослинний покрив предст влений гірськими т передгірськими лук ми $\mathrm{i}$ полонин ми, які використовують у сільському господ рстві. деревному скл ді лісів у передгір'ї рп т перев ж ють дуб звич йний, гр б звич йний, рідше тр пляється бук лісовий т ялиця біл . гірській ч стині н томість домінують угрупов ння 3 уч стю ялини європейської, бук лісового, ялиці білої т сосни кедрової європейської. долин х річок т потоків поширені вільх сір т чорн, т кож угрупов ння верби [18].

дослідженні використ но: 1) топогр фічні к рти м сшт бу 1:50 000, які відобр ж ли ситу цію н 1976-1989 рр.; 2) високороздільні космічні знімки з супутник QuickBird (2005-2006) т Spot (2008); 3) попередньо створений векторний природних морфогенних території п’яти місцевих р д [21]; 4) цифрову модель висот ( ) SRTM [25] т побудов ний н тї підст ві р стровий ухилів поверхні; 5) гр фічні м тері ли проектів роздерж влення і прив тиз ції земель ( ) досліджув них місцевих р д м сшт бу 1:10 000. ля опр цюв ння д них з стосов но прогр мне з безпечення для т , с ме: ArcGIS 9.2 [15].

ре ли зі змін ми н земного покриву виділяли у декільк ет пів. першу м ну льно, проте в середовищі 3 топогр фічними к рт ми т космічними знімк ми був 3 к ртов ний ст н н 1976-1989 т 2005-2008 рр., відповідно. створених м ну льно виділено чотири кл си - космічних знімк х це зроблено з використ нням методу візу льного дешифрув ння [17]. основу при виділенні кл сів взято кл сифік цію CORINE [26], яку використовують у кр їн х о кл су "нез ліснені землі" з числено ріллю, луки інтенсивного сільськогоспод рського використ ння (п совищ і сінож ті), т кож природні т н півприродні (вторинні) луки. ругий кл с “сукцесійні ділянки” охоплює ч г рникову рослинність, кущі т молоді дерев н місці покинутих лук бо лісових рубок. л с “лісові угіддя” об'єднує, відповідно, ділянки, з йняті хвойним, міш ним бо листяним лісом. кож в окремий кл с виділено “з будов ні територіі”, до яких з числено землі, з йняті житловою і промисловою з будовою, дорог ми (у меж х н селених пунктів) т прис дибні ділянки поблизу будинків. нші об'єкти, т кі як водойми, скельні відслонення, дороги т інші інфр структурні об'єкти поз меж ми з будов них територій, в окрему к тегорію не виділяли. роте в межі цих кл сів т кож потр пляють землі під водойм ми, скельними відслоненнями, дорог ми т іншими інфр структурними об'єкТ ми. ісцерозт шув ння цих природних т штучно створених об'єктів $€$ незмінним упродовж трив лого ч су, будівництво нових споруд, як з свідчило порівняння р дянських к рт із космознімк ми, н досліджув них територіях пр ктично не відбув лося. ому зміни в редукув - 
ли до змін, що відбулися між трьом кл с ми, з винятком кл су “з будов ні теритоpii”".

н слідок оверлею , що відобр ж є кту льний ст н фогенних , отрим но кту льних біогенних . вн слідок н кл д ння ост ннього н $\quad$ д дянського періоду вд лося визн чити н прям суч сних змін у меж х біогенних - росторов точність використ них у дослідженні м тері лів ст новить близько 30 м, тому в р зі розбіжності, меншої від цього зн чення, межу проводили по космічних зобр женнях, як достовірніших джерел х д них. усіх інших вип дк х вв ж ли, що відбулися зміни. ре ли площею до 0,02 г були вид лені. ключені до под льшого н лізу кл си д ли змогу розрізнити шість н прямів у диН міці

ля верифік ції результ тів дешифрув ння космічних знімків і, відповідно, точності к ртув ння кту льних біогенних використ но д ні $з$ точок польових спостережень. цьому р зі з стосув ли метод нечіткої кл сифік ції. тже, у вип дку збігу кл сів , дешифров них 3 космічними знімк ми, із визн ченими н місцевості, точці присвоюв ли коефіцієнт “1”. вип дку, коли кл си не збіг лися, проте н леж ли до сусідніх к тегорій (“нез ліснені землі” т “сукцесійні ділянки” бо "лісові угіддя" і “сукцесійні ділянки”), коефіцієнт відповідності ст новив “0.5”. інших вип дк х точці присвоюв ли коефіцієнт “0”.

ля оцінки впливу тр нспортної мережі території н процеси дин міки 3 н явними космозобр женнями створено р стровий тр нспортної доступності. p нспортну доступність визн ч ли н підст ві пок зників функціон льної, не евклідової відст ні до н явних доріг [6]. ункціон льну відст нь вимірюють в умовних метр х і, в н шому вип дку, розр ховують н підст ві відст ні до н йближчої дороги чи 3 будов ної території т прохідності території. оефіцієнт “опору”, що х р ктеризує прохідність території, з лежить від зн чення ухилів поверхні, д ні про які мітяться у відповідному . н чення ухилів поверхні поділили н 5 (ухил/5+1) і т к розр хув ли “опірність” території. ідд леність від доріг т поселень розр хув ли як добуток “опірності" території т відст ні у метр х. трим не зн чення відобр ж є відст нь 3 ур хув нням з тр т н її подол ння i, отже, є не лише просторовою, , певною мірою й економічною х р ктеристикою території.

крім того, з к ртов но просторову структуру землекористув ння території досліджув них місцевих р д. ля цього використ но гр фічні м тері ли 1:10 000, уточнені з використ нням д них . території дослідження всі землі 3 типом землекористув ння були об’єдн ні в чотири групи: “держ вні ліси” (підпорядков ні ерж вному гентству лісових ресурсів кр їни); “комун льні ліси” (підпорядков ні обл сному комун льному спеці лізов ному “ лсільліс"); “н селені пункти”; “сільськогоспод рські землі, землі з п су т резервного фонду”.

допомогою зон льних ст тистичних оверлеїв викон но порівняння структури біогенних 3 г лом т зі змін ми зокрем 3 попередньо розр хов ними кількісними т якісними л ндш фтними пок зник ми.

о головних результ тів цього дослідження н леж ть кту льних біогенних т змін цих . $\mathrm{x}$ р ктером змін між досліджув ними територіями є зн чні відмінності. окрем , у чотирьох модельних місцевих р д х, 3 винятком гуєвичів, перев ж ють т кі типи змін , які сприяють збільшенню лісистості території. хоч нтропогенні зміни поряд із природними можуть м ти відновлюв льний х р ктер, у цьому дослідженні прийнято, що нтропогенні зміни є винятково дегр тогенні, 
природні, н вп ки, - формуючі. ерші три типи змін біогенних у т блиці (злів н пр во) вв ж ємо природними формуючими, інші три, н вп ки, - дегр тогенними. рипуск ємо, що відновлення корінних чи н ближених до корінних рослинних угрупов нь відбув ється вн слідок посл блення чи повного припинення нтропогенного впливу.

піввідношення площ $\quad 3$ н прям ми змін, $\%$

\begin{tabular}{|c|c|c|c|c|c|c|}
\hline \multirow{2}{*}{\begin{tabular}{c} 
ентри \\
\cline { 2 - 7 } місцевих р д
\end{tabular}} & $\begin{array}{c}\text { пез ліснені землі } \\
\text { лісові угіддя }\end{array}$ & $\begin{array}{c}\text { нез ліснені } \\
\text { землі - } \\
\text { сукцесійні } \\
\text { ділянки }\end{array}$ & $\begin{array}{c}\text { сукцесійні } \\
\text { ділянки - } \\
\text { лісові } \\
\text { угіддя }\end{array}$ & $\begin{array}{c}\text { сукцесійні } \\
\text { ділянки - } \\
\text { нез ліснені } \\
\text { землі }\end{array}$ & $\begin{array}{c}\text { лісові } \\
\text { угіддя - } \\
\text { сукцесійні } \\
\text { ділянки }\end{array}$ & $\begin{array}{c}\text { лісові } \\
\text { угіддя - ліснені } \\
\text { землі }\end{array}$ \\
\hline $\begin{array}{c}\text { гуєвичі } \\
(1989-2005)\end{array}$ & 10 & 1,4 & - & - & 68,5 & 20,1 \\
\hline $\begin{array}{c}\text { т р іль } \\
(1989-2005)\end{array}$ & 53,2 & 9,8 & 8,0 & - & 25,4 & 3,6 \\
\hline $\begin{array}{c}\text { мельниця } \\
(1976-2006)\end{array}$ & 30,5 & 17,2 & 31,5 & 0,5 & 15,6 & 4,7 \\
\hline $\begin{array}{c}\text { оберк } \\
(1983-2008)\end{array}$ & 81,0 & 9,4 & 0,4 & - & 4,5 & 4,6 \\
\hline $\begin{array}{c}\text { сениця } \\
(1976-2005)\end{array}$ & 10,4 & 24,7 & 35,7 & 0,2 & 26,2 & 2,9 \\
\hline
\end{tabular}

г льн площ , н якій відбулися зміни у біогенних , ст новить: у гуєвич х - 58,8 г (2,3\% від площі сільр ди), т рій олі - 135 (4,2), мельниці - 582,7 (28,3), оберці - 733,5 $(10,8)$, сениці $-622,9$ г $(14,4 \%)$. ур хув нням ч сових інтерв лів, у меж х яких визн чено зміни біогенних , обчислено середньорічні темпи дин міки для кожної модельної території. тже, для території гуєвичів цей пок зник ст новить 3,7 г /рік, т рої олі-8,4, мельниці-19,4, оберки-29,3, сениці-21,5 г /рік. звемо особливості просторового розміщення біогенних , у яких відбулися зміни, по території місцевих р д (рис. 2). усіх п’яти вип дк х це території, розміщені в меж х лісових м сивів бо н узліссі. собливо ця з кономірність чітко помітн в гуєвич х т т рій олі. території оберківської сільської р ди простежено 3 кономірність, що більш ч стин зі зміною розт шов н у південній т північно-з хідній ч стин х. цих територіях до середини ст. були сел идьов i ікоть т ур вин, відповідно, які ч стково бо повністю потр пили у смугу поміж лінією прикордонних інженерних споруд т лінією держ вного кордону. ісля примусового виселення їхніх жителів т знищення з будови, ймовірно, поч лися процеси, спрямов ні н відновлення н ближених до корінних рослинних угрупов нь. і процеси відбув ються і з р з, тому з досліджув ний період можн спостеріг ти зн чні зміни у цих ч стин х території оберки.

підст ві н лізу розподілу змін з тип ми н ведемо т кі особливості.

г лом зміни ч стіше тр пляються в меж $\mathrm{x}$ випуклих схилів т вододільних поверхонь і рідше - у долин водотоків т увігнутих схилів. г льною рисою для усіх п’яти досліджув них територій є ч стіш появ змін у середньо- т сильносп - 

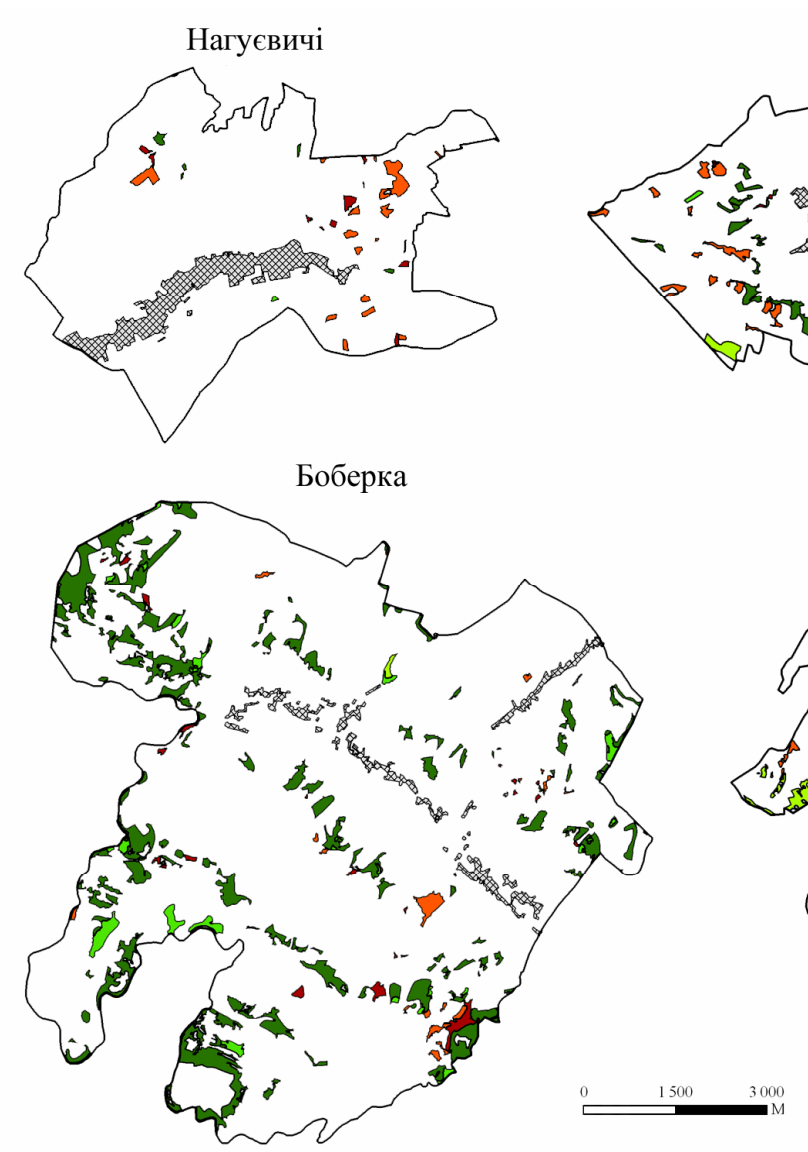

ис. 2. ин мік біогенних$$
\text { (1) будев ні }
$$

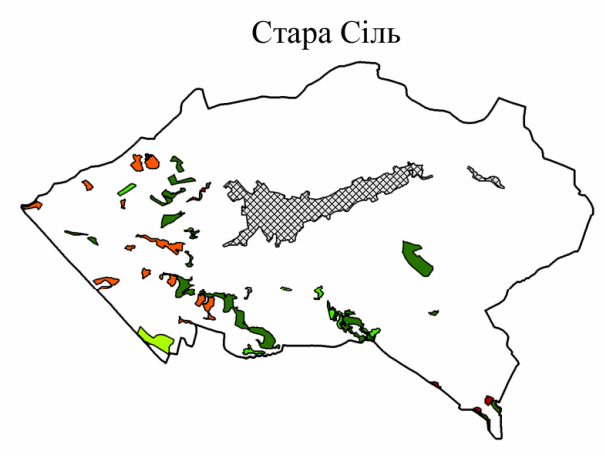

Ясениця

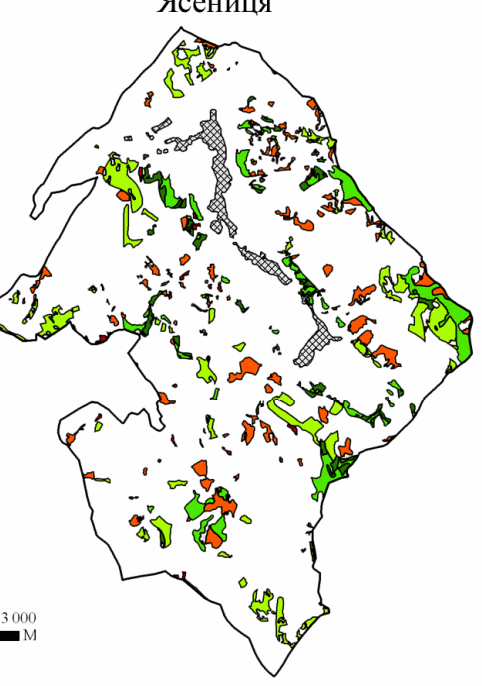

Н територіях досліджув них місцевих р д: 1 - з будов ні території; 2 - нез ліснені землі - лісові угідля; 3 - нез ліснені землі - сукцесійні ділянки; 4 - сукцесійні ділянки - лісові угіддя; 5 - сукцесійні ділянки - нез ліснені землі; 6 - лісові угіддя - сукцесійні ділянки; 7 - лісові угіддя - нез ліснені землі. 
дистих схилів, ніж н пологих місцях. кож можн стверджув ти, що зміни в біогенних ч стіше виник ють н свіжих мезотрофних ділянк х, для яких х р ктерні субформ ції потенційної природної рослинності (_ ) буково-дубових т ялицево(смереково)-букових лісів.

структурі біогенних зі змін ми можн помітити деякі спільні риси поміж досліджув ними територіями. прикл д, у мельниці т сениці н йбільш ч стк прип д $є$ н сильносп дистих випуклих т прямих схилів 3 типом ялицевобукових лісів т появою лісу н місці колишніх сукцесійних ділянок. $\quad$ т рій олі т оберці домінують біогенні середньосп дитих випуклих т прямих схилів зі зміною типу “нез ліснені землі-лісові угіддя” т угрупов ннями буково-дубових т ялицево-букових лісів, відповідно. гуєвич х перев ж ють зміни з ліснених релів н сукцесійні ділянки у меж х сл бковипуклих вершинних поверхонь 3 типом ялицево-дубових лісів т сл бкосп дистих випуклих т прямих схилів і типом гр бово-дубових лісів.

ля тр нспортно-геогр фічної х р ктеристики території досліджув них місцевих р д побудов но тр нспортної доступності. под льшому н лізі пок зники цього об’єдн но у п'ять груп: до 500, 501-1 000, 1 001-1 500, 1 501-2 000, пон д 2000 умовних метрів (умовн. м). озподіл ре лів зі змін ми по зон х тр нспортної доступності м є т кі особливості. гуєвич х т мельниці зміни ч стіше відбув ються в меж х 501-1 000 умовн. м від доріг т поселень. томість, у т рій олі т сениці зміни більше х р ктерні для , н ближених до доріг т поселень. озподіл цього пок зник у оберці м є особливий х р ктер, що зумовлено положенням поблизу держ вного кордону.

кож викон но порівняння модельних територій з структурою груп землекористув чів, включ ючи зі зміною . цим пок зником у передгірних модельних $\mathrm{p}$ д $\mathrm{x}-\mathrm{T}$ рій олі т гуєвич $\mathrm{x}-$ зміни рідше тр пляються у меж х сільськогоспод рських т резервних земель і ч стіше у меж х лісових м сивів, перед них у користув ння держ вним лісогоспод рським підприємств м. томість н території оберки т сениці спостеріг ється ситу ція протилежн до з зн ченої. мельниці зміни, як і в двох ост нніх сільських р д х, ч стіше тр пляються н сільськогоспод рських т резервних землях, т кож, як х р ктерно для передгірних досліджув них р д, н землях держ вних лісогоспод рських підприємств. чотирьох місцевих р д х, окрім мельниці, ч стк біогенних , що з зн ли змін у меж х комун льних лісів, є вищою, ніж по всій території з г лом. кож в усіх модельних місцевих р д х зміни у , які розт шов ні в меж х н селених пунктів, з фіксов ні зн чно рідше бо їх уз г лі нем , як у гуєвич $\mathrm{x}$.

еревірк точності к ртув ння суч сного , викон н 3 д ними 3 точок польових спостережень, пок з л дост тньо високі результ ти. очність к ртув ння ст новить: для території сениці - 74,5 \% (92 польові точки), оберки - 77,9 (60), гуєвичів 79,2 (69), т рої олі -81,5 (69) т мельниці - 82,1\% (53 точки).

ля території місцевих р д, які включені у дослідження, х р ктерним є ч стіш появ змін н територіях з ухил ми поверхні 6-12 т 12-20. плоских територіях, якими є долини річок, зміни у біогенних тр пляються менше через те, що ці землі н йбільше прид тні для ведення сільського господ рств , т кож н них розт шов ні н селені пункти. еоекосистеми стрімких схилів не використовують у сільському господ рстві, вони м лоприд тні для з готівлі т тр нспортув ння деревини, тому зміни в них поширені м ло. 
чотирьох 3 п'яти досліджув них місцевих р д (з винятком оберки) у меж х першої зони тр нспортної доступності (до 500 умовн.м) розт шов ні пон д 70 \%, у т рій олі - пон д $90 \%$ площ зі змін ми . ричиною цього є досить розг лужен мереж польових і лісових доріг т їхній рівномірний розподіл по території сільських р д, окрім оберки. оберці н першу зону тр нспортної доступності прип д є пон д $50 \%$, четверту т п'яту - пон д $20 \%$ площ біогенних , що з зн ли змін. н чн ч стк четвертої т п’ятої зон зумовлен відсутністю шляхів сполучення у присянській ч стині території р ди, де до кінця 1940-х років було декільк сіл, територія яких з р з у більшій ч стині розміщен $з$ лінією прикордонних інженерних споруд.

'ять досліджув них місцевих р д у розподілі змін у біогенних щодо структури землекористув ння можн розділити н дві групи. о першої групи з числено повністю бо ч стково розміщені в передгір'ї гуєвицьку сільську т т росолянську селищну р ди відповідно, до другої - сільські р ди мельниці, оберки т сениці. кщо для першої групи зміни у прит м нні територіям, що перебув ють у користув нні держ вних чи комун льних лісогоспод рських підприємств, то у другій групі т к дин мік н б г то ч стіше тр пляється н сільськогоспод рських землях, землях з п су т резервного фонду. енш сприятливі умови для ведення сільськогоспод рського виробництв у низько- т середньогірних р йон х кр їнських рп т порівняно 3 ередк рп ттям, імовірно, ст ли причиною припинення використ ння ч стини земель для сільськогоспод рських потреб.

езульт ти верифік ції з свідчили, що точність к ртув ння суч сного 3 космознімк ми н всіх модельних простор х ст новить пон д $70 \%$. оловною причиною т ких результ тів є те, що більш ч стин польових м тері лів (пон д 80 \%) зібр н влітку 2011 р., тоді як космічні знімки, які використовув ли у дослідженні зроблені у 2005-2008 pp. період між д тою знімків т збир нням польових д них, який в окремих вип дк х сяг є пон д п’ять років, т кож відбув лися зміни біогенних , серед яких н йм сшт бнішими т швидшими є вибіркові й суцільні лісові рубки.

тже, н території чотирьох $з$ п'яти досліджув них місцевих р д домінують процеси відновлення деревної т ч г рникової рослинності н місці колишніх сільськогоспод рських земель. продовж ост нніх десятиліть темпи зрост ння лісистості н території цих чотирьох місцевих р д ст новлять: 0,08-0,09\% 3 рік у т рій олі т сениці, 0,31 т 0,39\% з рік у оберці т мельниці, відповідно.

міни біогенних ч стіше тр пляються у місцях із середньо- т сильносп дистими ухил ми поверхні. розподілі змін щодо тр нспортно-геогр фічних х р ктеристик особливе місце м є оберк 3 вдяки специфічному розт шув нню т історії розвитку. кож відзн чимо, що процеси дегр д ції п совищ т орних земель у певних ч стин х території оберки трив ють із середини ст., що, імовірно, ч стково пояснює н явність зн чних площ зі змін ми

1. н тів . . р нсформов ність біогеоценотитчного покриву в меж х сільських р д гірських р йонів ьвівщини / . . н тів, . . рок, . . олив'ян // т лий розвиток рп т: суч сний ст н т стр тегія дій., ези доп. міжн. н.-П. конф. - ьвів : , 2006. - .46-48.

2. н тів . . р нсформов ність рослинного покриву т різном нітність гірських лісів ьвівщини / . . н тів // ісівництво і гролісомеліор ція : зб. н ук. пр. - рків : кр 2009. - ип. 115. - .240-244. 
3. олубеи . . иоценотический покров ескид и его дин мические тенденции / . . олубец, . . орсук, . . врилюк, . . л дунко и др. - иев : ук. думк , 1983. - 240 с.

4. родзинський . . снови л ндш фтної екології : підручник/ . . родзинський - . : ибідь, 1993. - 224c.

5. родзинський . . ізн ння л ндш фту: місце і простір. . 2 / . . родзинський. - . . ид вничо-полігр фічний центр “ иївський університет”, 2005. - 503 с.

6. $е$ ерс . . еогр фические нформ ционные истемы. сновы / пер. с нгл. / . . еерс. - . : т +1999 .

7. кон кр їни “ ро р тифік цію мкової конвенції про охорону т ст лий розвиток рп т”/ ерховн д кр їни. - . : ідомості ерховної ди кр їни, 2004. - № 32. - . 383.

8. кон кр їни “ ро р тифік цію вропейської л ндш фтної конвенціі” / ерховн д кр їни. - . : ідомості ерховної ди кр їни, 2005. - № 51. - . 547.

9. кологічн ситу ція н північно-східному м кросхилі кр їнських рп т / олубець . ., рискевич . ., озловський . . т ін.]. - ьвів : оллі, 2001.-162 с.

10. ойнов . . ндш фтно-типологічні особливості урківської ( трийсько- нської) верховини / . . ойнов / існик ьвів. ун-ту. ер. геогр. - 1964. - ип. 2 - . 35-43.

11. руглов . . ндш фт як геосистем / . . руглов // існик ьвів. ун-ту. ер. геогр. -2006. - ип. 33. - . 186-193.

12. руглов . . еліміт ція, метриз ція т кл сифік ція морфогенних екорегіонів кр їнських рп т / . . руглов // кр. геогр. журн. - 2008. - № 3. - . 59-68.

13. іллер . . рп ти кр їнські / . . іллер, . . едірко // еогр фічн енциклопедія кр їни: у 3 т. - . 2. - . : кр їнськ дянськ нциклопедія імені . . ж н , 1990. - . 113114.

14. ельник . . кр їнські рп ти: еколого-л ндш фтозн вче дослідження / . . ельник. ьвів : ім. . р нк , 1999. - 288 с.

15. ин ми . ArcМар. уководство пользов теля. . $1 /$. ин ми. - . : т +, 2001. -290 с

16. $y x$. . ндш фтн к рт ьвівської обл сті м сшт бу 1:200 000 / . . ьвів. ун-ту. ер. геогр. - 2003. - ип. 29. - . 58-65.

17. $p$ монов . . сновы топогр фии и эрофотосъёмки / . . p монов, . . омов, . . ерногл зов. - . : едр , 1991. - 236 с.

18. рирод ьвівської обл сті/з ред. . . еренчук - ьвів : ид-во ьвів. ун-ту, $1972 .-152$ с.

19. рирод кр їнських рп т/з ред. . . еренчук - ьвів : ид-во ьвів. ун-ту, 1968. $267 \mathrm{c}$.

20. м лійчук . ослідження суч сної дин міки геоекосистем низькогір'я рп т у меж х ьвівської обл сті з використ нням технологій // ізичн геогр фія т геоморфологія. 2010. - ип. 3(60). - . 83-92.

21. м лійчук . орфлогічн структур л ндш фтів низькогір'я рп т у меж х ьвівської обл сті / . м йлічук // ізичн геогр фія т геоморфологія. - 2011. - ип. 1(62). - .61-70.

22. рохимчук . . труктур л ндш фтів трийсько- нської верховини / . . рохимчук // існик ьвів. ун-ту. ер. геогр. - 1965. - ип. 3. - .25-29.

23. кр инские рп ты. рирод / под ред. . . олубц и др. - иев : ук. думк , 1988. 208 c.

24. Comber A.J. Using semantics to clarify the conceptual confusion between land cover and land use: the example of 'forest' / A.J. Comber, R.A. Wadsworth, P.F. Fisher //Jo-1 of Land Use Science. - 2008. - Vol. 3. - N. 2-3.- . 185-198.

25. Jarvis A. Hole-filled SRTM for the globe Version 4 [Electronic resource] / A. Jarvis, H.I. Reuter,

. Nelson, E. Guevara // CGIAR-CSI SRTM 90m Database, 2008. - ежим доступу: http://srtm.csi.cgiar.org. 26. Bossard M. CORINE land cover technical guide / M. Bossard, J. Feranec, J. Otahel. - EEA, Copenhagen, 2000.

27. Kruhlov I. Natural geoecosystems / I. Kruhlov, B. Mukha, B. Senchyna // Transformation processes in the Western Ukraine: Concepts for sustainable land use. - Berlin, 2008. - . 81-97.

28. Lambin E.F. Introduction: Local processes with global impacts / E.F. Lambin, H. Geist, R.R. Rindfuss // Land use and land cover change: Local processes and global impacts. - Berlin, 2006. - . 1-9. 
29. Kuemmerle T. Cross-border comparison of land cover and landscape pattern in Eastern Europe using a hybrid classification technique / T. Kuemmerle, P. Hostert, K. Perzanowski, V.C. Radeloff // Remote Sensing of Environment. - 2006. - Vol. 103. - P. 449-464.

30. Kuemmerle T. Cross-border comparison of post-socialist farmland abandonment in the Carpathians. / T. Kuemmerle, P. Hostert, V.C. Radeloff et al. // Ecosystems. - 2008. - Vol. 11. - P. 614-628.

31. Kuemmerle T. Forest cover change and illegal logging in the Ukrainian Carpathians in the transition period from 1988 to 2007 / T. Kuemmerle, O. Chaskovskyy, J. Knorn et al. // Remote Sens. Environ. 2009. - Vol. 113. - P. 1194-1207.

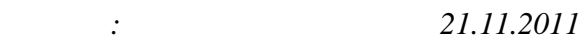

\title{
GEOECOLOGICAL ANALYSIS OF MODERN LANDSCAPE DYNAMIC OF THE LOW MOUNTAIN UKRAINIAN CARPATHIANS
}

\author{
A. Smaliychuk \\ Ivan Franko National University of Lviv, \\ . Doroshenko St., 41, UA - 79000 Lviv, Ukraine
}

This paper analyses change of land cover, as central component of biogenic geoecosystems (GES), with respect to the natural landscape structure, proximity to roads and settlements and land use structure. Five model municipalities were selected in the low mountain Ukrainian Carpathians. The land cover pattern of 1970-80s was digitized from the topographic maps, while its recent change was manually detected using high resolution images. After the natural GES data were overlaid with actual land cover the biogenic GES were distinguished. Six types of LC change were detected in this study. A common trend ion study areas is the increase of the forested area owing to forest succession on former agricultural land.

Key words: Ukrainian Carpathians, geoecosystems, land cover, modern dynamic, GIS.

\section{A. м лийчук}

ввовский н цион льный университет имени в н р нко, ул. . орошенко, 41, г. ввов, 79000, кр ин

ро н лизиров но изменения н земного покров , к к центр льного компонент биогенных геоэкосистем, н фоне структуры природных л ндш фтов, тр нспортной инфр структуры и структуры землепользов ния. ля исследов ния избр но пять модельных сельских советов в низкогорье кр инских рп т. к основные д нные использов ны советские топогр фические к рты и космические снимки с большим p зрешением. осле н ложения структуры современного н земного покров н к ртогр фический слой природных морфогенных геоэкосистем уст новлены биогенные геоэкосистемы. ри выделенные кл ссы н земного покров позволили р зличить шесть н пр влений в дин мике геоэкосистем. бщей тенденцией является рост лесистости бл год ря дегр д ции бывших сельскохозяйственных угодий.

лючевые слов : кр инские рп ты, геоэкосистемы, н земный покров, современн я дин мик , 